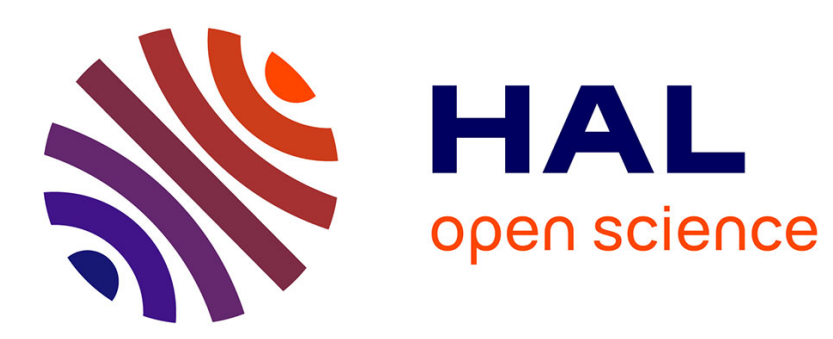

\title{
From Atomic Fission to Splitting Areas of Expertise: When Politics Prevails Over Scientific Proof
}

\author{
Cécile Asanuma-Brice
}

\section{To cite this version:}

Cécile Asanuma-Brice. From Atomic Fission to Splitting Areas of Expertise: When Politics Prevails Over Scientific Proof. Planetary Atmospheres and Urban Society After Fukushima, 2017. hal02572990

\section{HAL Id: hal-02572990 \\ https://hal.science/hal-02572990}

Submitted on 26 May 2020

HAL is a multi-disciplinary open access archive for the deposit and dissemination of scientific research documents, whether they are published or not. The documents may come from teaching and research institutions in France or abroad, or from public or private research centers.
L'archive ouverte pluridisciplinaire HAL, est destinée au dépôt et à la diffusion de documents scientifiques de niveau recherche, publiés ou non, émanant des établissements d'enseignement et de recherche français ou étrangers, des laboratoires publics ou privés. 
Planetary Atmospheres and Urban Society After Fukushima 
"Carrying the reader across a varied terrain-from the operations of capitalism and politics, to the physical ground of everyday life; from sign systems and the status of the image to love, and the affective organization of life-Planetary Atmospheres and Urban Society After Fukushima critically reveals these as part of a common assemblage of processes in which we are all implicated. In an argument for relation without limits or end, Fukushima Japan can here be seen as central to the contemporaneity of our world, now."

- Thomas D. Looser, Associate Professor, Department of East Asian Studies, New York University, USA

This collection examines the event of Fukushima in Japan in terms of urban sociology and cultural politics to portray the triple catastrophe of March 2011 as both a planetary event and a dual economic and environmental crisis which indelibly marked Japan and the wider global community. The contributors examine how this new situation has been expressed in particular cultural forms (literature, film), political discourses, and urban everyday life in Tokyo and Fukushima, arguing for an imperative need to redefine the national frame of analysis in terms of the concept of the planetary. Building on recent debates in ecocriticism, Planetary Atmospheres and Urban Society After Fukushima deconstructs the spatial logic of containment that reduces the event of Fukushima to a place-bound object to instead reinscribe this event within an open narrative of the planetary. This we believe will allow us to redefine our topologies of attachment to local places beside national discourses of unity, resilience, and global strategies of risk management, and open the way to a radical rethinking of Japan's cultural politics afterMarch 2011.

Christophe Thouny is Assistant Professor in the Center for Global Communication Strategies at The University of Tokyo, Japan. His research interests focus on the modern urban experience in Japan in relation to nationalism, globalization, and environmental problems.

Mitsuhiro Yoshimoto is Professor at the School of International Liberal Studies at Waseda University, Japan.

\section{palgrave macmillan}

ISBN $978-981-10-2006-3$ ||||||||||||||||||||||||||||

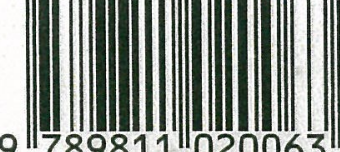

9 $1789811 \|_{020063}$ 


\section{Christophe Thouny - Mitsuhiro Yoshimoto Editors \\ Planetary \\ Atmospheres and \\ Urban Society After \\ Fukushima}

palgrave macmillan 


\section{From Atomic Fission to Splitting Areas of Expertise: When Politics Prevails Over Scientific Proof}

\section{Cécile Asanuma-Brice}

"Hiroshima is everywhere," wrote Günther Anders, and everything suggests that, despite all manner of humanist discourse, mankind has not yet chosen that it be any other way. During the commemoration of the seventieth anniversary of the atomic bombing of Hiroshima, the Japanese Prime Minister, Shinzo Abe, omitted a key phrase from his speech in homage to the victims, namely, the three principles of nuclear non-proliferation reaffirmed each year by his predecessors: [Japan] "will not possess, produce, or import nuclear weapons" (koku heiki wo motazu, tsukurazu, mochikomezu). ${ }^{1}$ The omission was no mere oversight, for his government has just made a unilateral decision to revise the constitution so as to allow for Japan to carry out military operations abroad, as well to facilitate nuclear agreements on the commercial side. We will very likely be accused of confusing two distinct notions: nuclear energy and nuclear weaponry, as if, passing from a civil to a military function will change its fundamental nature. ${ }^{2}$ A review of the history of the nuclear industry's beginnings, though, will quickly dispel such naive arguments ${ }^{3}$; and, of course, it must be remembered that it is from our "peaceful" uranium plants that the military is able to acquire its plutonium. ${ }^{4}$ That it is in fact the same entity that is reinforced

C. Asanuma-Brice (区)

Maison Franco-Japonaise, Tokyo, Japan

(C) The Author(s) 2017

C. Thouny, M. Yoshimoto (eds.), Planetary Atmospheres and Urban

Society After Fulushima, DOI 10.1007/978-981-10-2007-0_6 
by the gorermment's actions: the drive to pare the way for Japan's retum to armed contlict bas been accompanicd simultaneously by a concerted effort to put the Fukushima disaster into the past, and as quickly as possible. Capitalizing on the fat that, although the effects of the catastrophe are still being dealt with, the menace is more and more a familiar, even annoying, presence, the gowermment made the decision to resume operations at the Sendai nuclear plant on Küushu on August 14, 2015.5

But irrationality and contradictions that strain belief also play a large role in nuclear matters, as evidenced by another change in government policy. Just as an important international study announced its results showing a clear link between leukemia and long-term exposure to lowdose radiation, the Japanese government-with the support of the International Atomic Energy Agency-increased the acceptable dose for nuclear workers from 100 to $250 \mathrm{msv} / \mathrm{year}$ in cases of emergency. ${ }^{\circ}$ It is worth recalling that this same norm had been set at $20 \mathrm{msv} / \mathrm{year}$ prior to the explosion at Fukushima Daiichi, and was then raised following the accident to $100 \mathrm{msv} / \mathrm{year}$ for nuclear workers and $20 \mathrm{msv} / \mathrm{year}$ for the civilian population.

Because this threshold is used as the basis for all measures protecting and managing the population, its importance surpasses the purely epidemiological domain to have multiple and wide-ranging consequences.

The first is the increase by the authorities of the radiation dose considered acceptable for the general population. Despite all the epidemiological evidence signaling the grave health risks of an environment below $100 \mathrm{msv} /$ year, the political authorities are henceforth using this as a basis of reference, so as to stabilize the benchmark for the whole of the population at $20 \mathrm{msv} / \mathrm{year}^{7}$

Other consequences appear in civil protection policies, since it is this threshold that is used to determine which zones should be evacuated for their health hazards and which not. From there derives the totality of measures for protecting residents, most notably the housing policy under which a government can control the movements of its population and where it is settled.

\section{The Epideniological Effects of Nuclear Exposure: EVEN INWORKS DOESN'T WORK}

An international cohort study called INWORKS (International Nuclear Workers Study), on "ionizing radiation and risk of death from leukemia and lymphoma in radiation-monitored workers," was undertaken to dispel 
ave the way for Japan's return to Itaneously by a concerted effort ast, and as quickly as possible. affects of the catastrophe are still more a familiar, even annoying, on to resume operations at the : $14,2015.5$

it strain belief also play a large mother change in government al study announced its results ad long-term exposure to lownt-with the support of the sreased the acceptable dose for ar in cases of emergency. ${ }^{\circ}$ It is been set at $20 \mathrm{msv} /$ year prior $d$ was then raised following the irkers and $20 \mathrm{msv} / \mathrm{year}$ for the Wro

is for all measures protecting Ay surpasses the purely epide4. Wanging consequences.

7. 6 - the radiation dose conWhespite all the epidemio36f an environment below 6. He. whole of the popula13)

Wicies, since it is this Wuld be evacuated for trves the totality of ysing policy under tis population and

HXOSURE:

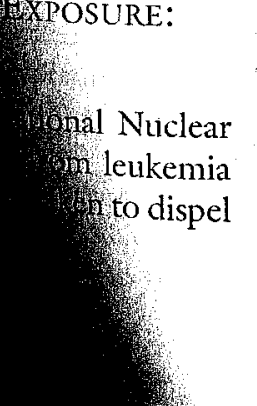

the uncertainties regarding the connection of these diseases to protracted exposure to low-dose radiation. This study, carried out by 13 researchers in epidemiology, each from a different laboratory, was made public in June 2015. Its funding came from the Centers for Disease Control and Prevention (USA); the Ministry of Health, Labor and Welfare of Japan; the Institut de Radioprotection et de Sûreté Nucléaire, AREVA, Electricité de France; the National Institute for Occupational Safety and Health (USA); the US Department of Energy; the US Department of Health and Human Services; the University of North Carolina; and Public Health England. Financing was thus provided in part by those directly involved in the interests of the nuclear microcosm, but the authors of the study specify that at no time did they intervene in the either the research or its publication: their sole role was to allow access to data. This study consisted of following no fewer than 308,297 workers who had been employed in a nuclear facility for at least one year. The employers were as follows: in France, the Atomic Energy Commission (CEA), AREVA Nuclear Cycle, or the national electricity company (EDF); in the USA, the Departments of Energy and Defense; in the UK, nuclear industry employers listed in the National Registry for Radiation Workers. The method used to follow the health of the workers was Poisson regression, a linear model of logarithmic functions, in order to quantify the associations between the dose absorbed by bone marrow and the mortality rate for leukemia, lymphoma (tumors that develop from lymphatic cells), and multiple myeloma.

The principal source of information for evaluating the link between ionizing radiation and cancer has long been the body of data amassed through epidemiological monitoring of the survivors of the two atomic bombs dropped on Hiroshima and Nagasaki by the USA in August 1945. Their analysis proved the causal link between exposure to ionizing radiation and the development of leukemia. However, these results concerned only exposure to acute, high levels of radiation. Yet it is sustained or repeated exposure to low-dose radiation that is more and more an issue in today's society. It has been shown, for example, that average annual doses of ionizing radiation (from medical exposure) in the USA rose from $0.5 \mathrm{mGy}$ per person in 1982 to $3.0 \mathrm{mGy}$ per person in 2006 . This phenomenon has also been observed in most other high-income countries. ${ }^{9}$ For its part, the study carried out by the team of INWORKS researchers proves the correlation between the risk of death from leukemia and prolonged exposure to low doses of radiation, through the monitoring of the subjects over a period of 60 years. 
But since nothine stops those who insist on applying the cost-benefit nom AlARA-As Low As Reasonably Acceptable" -our lives depend less on any cpidemiological evidence than on the notion of "reason." In this way, demagroguery on the matter has led to the term "rictim" being replaced by the less charged term "affected persons." This change of terminology, notably in the documents of the ICRP," is not without consequence: in psrehology, affect is opposite to intellect, and as such engenders behaviors that are not rationally based. In psychology, too, affectivity is contrary to cognition, that is, the capacity for rational reasoning, although this dichotomous approach has become more nuanced over time. Additionally, the use of the term "affect" here alludes to the idea of radio-phobia, the irrational fear generated by a (nuclear) danger that is little understood, acoording to its defenders. Recently, the ICRP decided that the term "radio-phobia" as previously used was an error. According to their new approach, it is normal for people to be afraid, given their relative ignorance. Therefore, it is important to put into place a program of education to correct the widespread lack of knowledge. This logic, however, contradicts that developed by the same people in applying ALARA: "we don't know scientifically what the health effects are of low levels of radioactivity, so we must just deal with the situation on the ground." The key, therefore, is to find a way to teach what one does not know. This says a lot about the weight given to simple communication in the matter. Communicating does not equal informing; communication amounts to inculcation, through public relations, propaganda the goal of which is to make people accept a doctrine that has been politically (but not scientifically) established.

To go "as low as reasonably acceptable" (ALARA) also means, according to Jacques Lochard, speaking at a June 2015 symposium on the ethics of radioprotection, that "the right of refuge could not be one of the radioprotection rules. We have to accept the situation and deal with it." Deborah Oughton (CERAD) added that "we must educate people as to the risks in order to make the risk more acceptable."12 What's important is to know by whom this risk must be accepted and why. These couple of extracts, of talks chosen from among many others, lead us to question what is certainly one of the major preoccupations of society today, namely, the fact that those who actually do the risk-taking are rarely the ones who benefit from the risks taken, and as such the situation cannot be acceptable. 
Ang the onst-benefit 7our lives depend totion of "reason." Whe term "rictim" tons." This change Qp?" is not without Hellect, and as such apsycholosy, too, for rational reasonthore nllanced over Whades to the idea (it) danger that is The IC.RP decided error. According Xeiven their relaHe a program of Whis logic, how' Wolying ALARA: tof low levels of Whe ground." thot know. This Wh in the matter. Wn amounts to W. of which is to Hit not scientifi(3)

7heans, accord3in on the ethro one of the Whal with it." 14tepeople as to 74: important These couple of us to quesHociety today, Wre rarely the irg cannot be

The Residental, ElFets of Nuchar Exposurl:

"Becaush Housing is Lift.."

Who then, in the present case, are thys
have they managed this risk-taking?

The people who fled the territories contaminated by radioactivity, fol lowing the explosion at TEPCO's Fukushima Daiichi nuclear plant, have been classified into two groups: the 80,000 inhabitants of the $11 \mathrm{com}$ munes within the evacuation zone (see Figs. 6.1 and 6.2 below) and those who migrated of their own initiative, haring recelicd no gor zone ment directives that might have protected them. (1he ealtry section of extending $20-30 \mathrm{~km}$ around the plant which produce the illusion of the contaninated land.) Our societies, disasters by the use of measurecontrol over social, natural, and he castes. In this way, a new category ment, thereby become producers of castes.

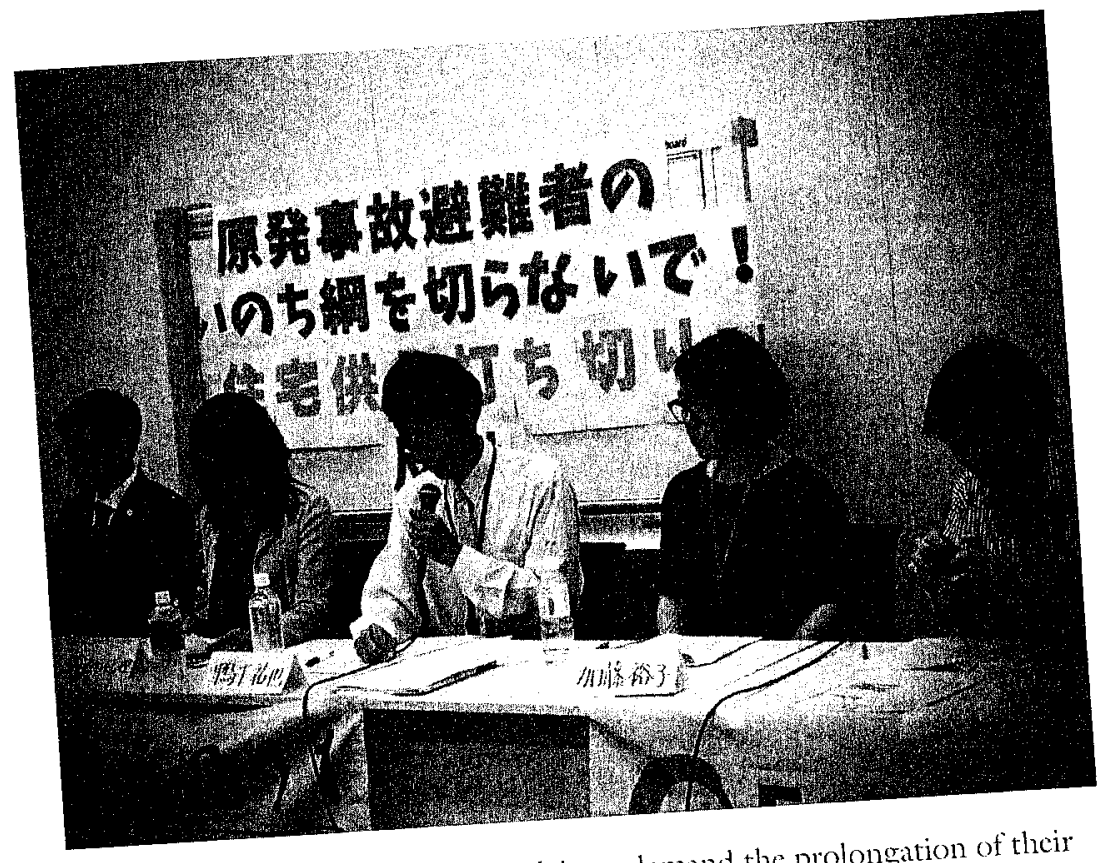

Fig. 6.1 Refugees and their legal advisors demand the prolong 20, 2015 (Photo access to tiree housing Cécile Asanuma-Brice) 


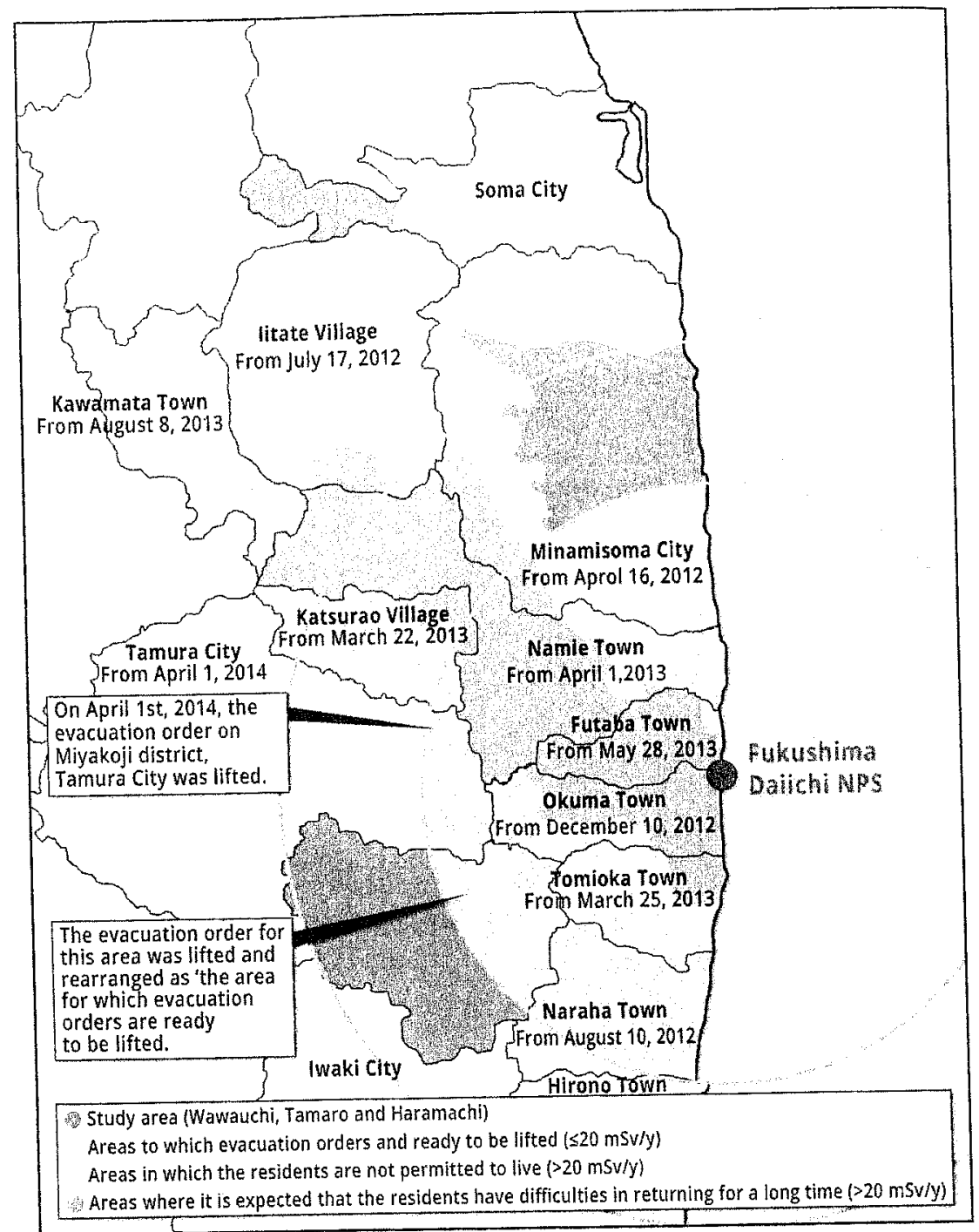

Fig. 6.2 Map of the restricted arei 

As for the prefecture, it justifies its decision by the fact that extending refugee conditions acts as a brake on reconstruction. One might, howerer, question the pertinence of a reconstruction that would subject the population to low doses of dangerous radiation, as evidenced by the results of the INVOORK study previously discussed. Without waiting any longer, the Japanese goremnent reauthorized, for the first time, part of the full evacuation zone to be habitable once more. The town of Nabara thus reopened its doors on September 5, 2015. Fewer than $10 \%$ of the municipality's 7500 residents applied to return to the town, which lacks basic commercial and medical services."

\section{The Progressive Reophing of the Evacuation Zone}

Behind these measures lies a determination to reopen the evacuated zone, following the decision by the Japanese government to pursue its use of nuclear energy. The issue then is to show that a government is capable of handling a nuclear disaster, by minimizing its management of it, even though, in order to do so, it must put part of its population in danger. Add to that the decontamination policy, a colossal undertaking, which is just one more calamity given the damage it causes, and even then is only partially effective: it is impossible to clean all the foliage, mountains, and Waterways. Tons of radioactive waste have been stored in sacks, some already torn, along the oceanfront, just waiting for the next tsunami to spread out again upon the continent. Thus, all the analytical elements line up together to demonstrate that the international political management of the explosion at the Fukushima nuclear plant is mired in a layer of conscious deception, built upon the fundamental infrastructure of all politics: the lie. ${ }^{20}$

\section{The Psichological Effects of Nuclear Energy: A Point of No Return}

We established a first assessment in December 2014 of the number of victims of this management of the crisis, as disastrous as the disaster itself, accounting for 1170 deaths related to the explosion at the TEPCO nuclear plant. ${ }^{21}$ Contradicting the rumors circulated by some researchers, notably at the Fukushima Medical University, according to which cases of depression and suicide had multiplied within the refugee population due to their estrangement from their hometowns, a recent study led by 
ion by the fact that extending struction. One might, however, a that would subject the popu, as evidenced by the results of 1. Without waiting any longer, $r$ the first time, part of the full re. The town of Nahara thus Fewer than $10 \%$ of the municito the town, which lacks basic

\section{Whe Evacuation Zone}

Treopen the evacuated zone, 1) 17t a government is capable 4ts management of it, even 40ts population in danger. 7xissal undertaking, which Wuses, and even then is Whe foliage, mountains, Hotored in sacks, some Wthe next tsunami to 13. Ganalytical elements 1 th political manageIs mired in a layer 17frastructure of all

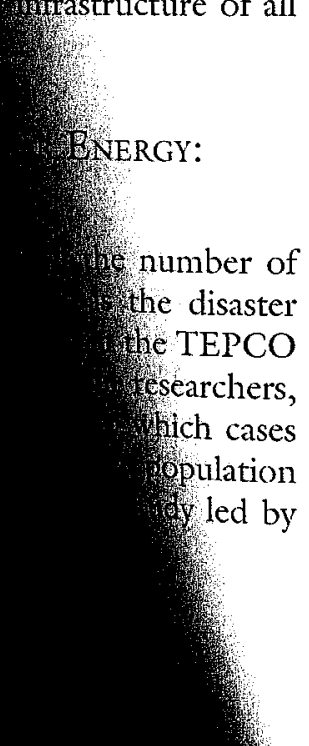

professor Takuya Tsujiuchi, director of the Waseda Institute of Medical Anthropology on Disaster Reconstruction, on 16,000 refugees show that over $40 \%$ of them suffer from post-traumatic stress disorder (PTSD). These results further indicated that the number of traumatized individuals was equivalent between those who had been ordered to evacuate and those who took refuge voluntarily. Professor Tsujiuchi, interviewed by the national broadcaster NHK on May 27, 2015, explained that to constrain these people to return to live in the place where their psychological disorder began, while its environment remains unstable due to current contamination levels and the decaying state of the nuclear plant, could have dramatic consequences. He points out that, in contrast to the results of post-traumatic testing following an earthquake, this study shows that the victims are not confronted by a single stress in managing their everyday lives, but suffer from genuine mortal anguish faced with the nuclear menace. According to Professor Tsujiuchi, "we act today as though the catastrophe is over, but that is not the case. We're cutting housing aid, and then indemnities for psychological suffering, then financial compensation for loss of belongings... Soon, there will be no more aid. The situation is very dangerous."

The "voluntary" refugees are, for the most part, single-parent families, who worry about the health consequences of educating their children in contaminated areas. The loss of housing aid would thus greatly accentuate their already considerable vulnerability. Legal aid associations have argued that the law that limits refugees' stay in the emergency housing units to two years is based on their instability due to hasty construction and the use of flimsy materials, yet this is not true of the minashi kasetsu jütaku, which are ordinary lodgings. In addition, the policy of reconstruction is advancing very slowly: the number of public housing units actually built on the refuge site is just 509 out of the 4890 that were planned. Yet despite three calls for applications, the occupation rate for these 509 units remains very weak. The principal reason for this resistance comes from the fact that the prospective inhabitants would not only lose their current rent-free arrangements, but they would have to live in collective housing. For this population, who were mostly farmers consuming the fruits of their own production, to accept such housing would mean entering into a costly system of consumption that they had always avoided; worse, in doing so, they would definitively give up hope of ever living again in a rich, natural environment as had been theirs. The words of Mrs. Monma, a 75-year-old 
Budthist num from the tomn of Namic, put this in clear terms: "we simply want houses where we can farm the land (Fig. 6.3). ${ }^{n 22}$

The remarks of Ulrich Beck come to mind: "Risk societies uniformly place humanity in a situation where it puts itself in danger through the intermediary of civilization." "2. This example shows us how this process of self-destruction is set up in our societies, which nonctheless continue to boast of their level of civilization achieved through the derelopment of the system of economic production that sustains then. Likewise, the Japanese government calls for a return to life in the contaminated areas, all the while refusing the massive investment needed to reconstruct the depopulated countryside, an area that it had in fact already abandoned in faror of urban economic viability.

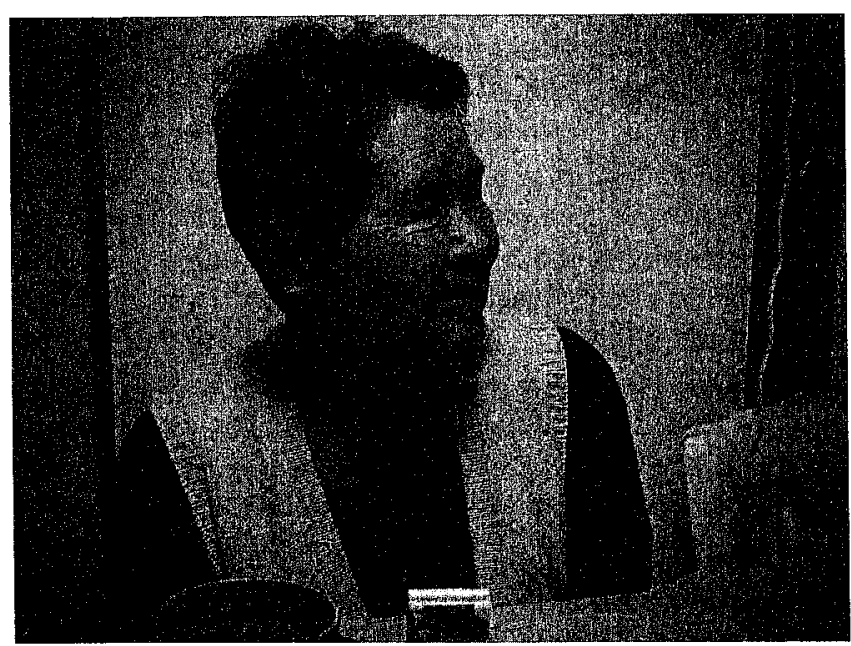

Fig. 6.3 Ms. Monma, a 75-year-old Buddhist nun from the town of Namie, living as a refugee in the village of Ōtama: "I went to demonstrate before the Parliament, I said to them..., we have lost everything..., we simply want houses where we can farm the hand" (Interview conducted May 21, 2015; Photo Cécile Asanuma-Brice) 
in clear terms: "we simply ..3). ."22

"Risk societies uniformly elf in danger through the hows us how this process hich nonetheless continue through the development stains them. Likewise, the in the contaminated areas, needed to reconstruct the fact already abandoned in

\section{LiES AND PUNishMENT}

As we have seen through various angles of approach, the disconnect As we have seen through acts is deepening, so a philosophical approach
between reality and political acts
to the problem is needed if we are to understand, and thus better confront, the cause of such commitment to this self-destructive behavior

What is the reality here? The reality is scientific proof of the dangers of nuclear radiation even at low doses (see the INWORKS study); the demonstration that social management of such an accident is impossible, no matter the level of wealth or education of the country involved; confirmation of the fact that nuclear energy is not economically cost-effective, that is, profitable or feasible (the soaring deficit at AREVA in 2014 reinforces the two reports of the Cour des Comptes, the French Auditor General's Office, which had already called into question the deplorable financial situation of the nuclear industry ${ }^{24}$; and scientific confirmation that nuclear energy is not the perfect solution to reducing $\mathrm{CO}^{2}$ emissions, since it itself produces them, as for example during the extraction and processing of uranium. Therefore, nuclear production is not necessary-in the philosophical sense of the term, that is, what is and must not be-to life in our societies. It should also be noted that we possess today other means of meeting our energy needs, the performance of which could be rapidly increased if our governments decided to devote even a quarter of the budget that now goes to developing nuclear research. ${ }^{25}$ Finally, our energy consumption could be considerably lessened, if we address the wastefulness-at the industrial level as much as among individuals (e.g., dependence on home automation)-that characterizes the modes of over-consumption in the rich countries of our planet. ${ }^{26}$

What, therefore, are the motivations of those who, counter to all good sense, make the decisions to pursue and develop a form of energy that holds the ultimate power of to be or not to be?

\section{When the Deaths of Some Become a Bull Market FOR OTHERS}

As we noted in a previous article, Mitsubishi, the prince of Japanese home automation and electric cars, having expanded into the armament industry, participated for the first time in 2014 in the international armament exhibition Eurosatory. Mitsubishi Heavy Industries created a joint venture with AREVA under the name ATMEA, beginning in 2007, with the goal 
of developing sales of the EPR (European Pressurized Reactor) and the APWR (Adranced Pressurized Water Reactor). On May 3, 2013, Turkish Prime Minister Recep Tayyip Erdogan and Japanese Prime Minister Shinzo Abe signed a \$22 million contract to construct the Sinop Nuclear Power Plant in Turkey. The owners of the power plant are Mitsubishi Heavy Industries and Itochu for Japan, who, together with the French AREVA and GDF Suez, account for $65 \%$, and the Turkish public energy producer EUAS with $35 \% .^{2-}$ Political instability in the region can only increase our concern regarding the resolve of the Japanese government to do what is needed to join with the various countries of the coalition against the Islamic State (ISIL, Daesh) who came together in 2014, during the war in Iraq and the civil war in Syria, to intervene militarily against the Islamic State and the Al-Nosra Front in Iraq and Syria. These military actions, primarily undertaken by the Americans, involve 21 other countries, including France and the other principal countries of Europe, but also Canada, one of the world's primary sources of uranium. These wars are an arms market without end. For example, in February 2015, France sold 24 Rafale fighter planes to Egypt; in April, 34 to India; then Qatar decided to buy 24 , for a total of 6.3 billion euros. ${ }^{28}$ To make matters worse, the use of weapons and munitions containing depleted uranium in these various con flicts has yet to be regulated, the USA, UK, France, and Israel all rejecting a UN resolution on the matter in October $2014 .^{29}$

\section{From the Illusion of Citizen Participation to Shaking the Democratic System}

The reflections that follow carry on from the works of Günther Anders, Hannah Arendt, and Hans Jonas on the subject. They put forth the idea that man had arrived at a stage where knowledge and thought had become disconnected in the face of the impact, in a distant future, of what he produces. The enormity of the consequences over the long term-and in the short, as the influx of migrants fleeing Syria demonstrates-of what we produce, weakens our capacity to represent those consequences, faced with a capacity to produce that is quasi-immediate. Accompanying this temporal dislocation, modern science allows domination of nature to take the place of its contemplation, establishing a technological power that sets itself up as an invincible opposite to nature's vulnerability. In this way, humanity becomes aware of its power to influence the planet's entire biosphere, thereby generating a new approach to the principle of 
surized Reactor) and the Jn May 3, 2013, Turkish ese Prime Minister Shinzo the Sinop Nuclear Power int are Mitsubishi Heavy with the French AREVA sh public energy producer rion can only increase our government to do what the coalition against the in 2014, during the var litarily against the Islamic These military actions, priother countries, including Qpe, but also Canada, one se wars are an arms mar7. France sold 24 Rafale W Q Qatar decided to buy 7htters worse, the use of Win in these various conXnd Israel all rejecting

\section{ICIPATION}

औTEM

1f Günther Anders, 10ut forth the idea W.ught had become tixture, of what he 106ng term-and in Whitrates-of what risequences, faced Impanying this 1) of nature to togical power vulnerability. ethe planet's principle of responsibility. Furthermore, the existence of ethics constrains prescient knowledge to the recognition of ignorance, in that it is slight in comparison with technical knowledge. The managers of nuclear matters have well grasped the necessity of an ethical showcase to mollify public disquiet, and will go to the lengths of promoting ignorance, even scientific falsification, as a means to ward off potential attacks on their actions.

As Hans Jonas remarks in The Imperative of Responsibility,

The sacrifice of the future is logically no more open to attack than the sacrifice of the present for the future. The difference is only that in the one case the series goes on, and in the other it does not... However, the new imperative says precisely that...we do not have the right to choose, or even risk, nonexistence for future generations on account of a better life for the present one... [The statesman's] endeavor is to create a viable political structure, and the test of viability is in the enduring of his creation. ${ }^{30}$

Nuclear industrialists thus assume an untenable right and, by doing so, unleash an imperative of responsibility that is much too heavy to be borne by its holders alone. It is the reason that the nuclear sector introduced the participative system, so that rather than minimizing the risks, it ensures that they are accepted, and even that the responsibility for them is shared, by giving the parties concerned the illusion that they participate in the decision-making process. But another characteristic of the nuclear industry is that its increased stature-which is purely a product of public policyenables it effectively to ignore the opposing masses to which it accords but a semblance of meaningful involvement. This dictatorial nature is inherent in the nuclear establishment, which makes a mockery of the democratic system, pushing it to the outer edges, as we can see in this photo taken in October 2014, while the Japanese government was deciding to restart the country's first nuclear operations (at the Sendai plant on Kyūshū) in four years, even though the population energetically expressed its opposition (Fig. 6.4):

A small number of Japanese politicians thus made the decision to relaunch Japan's nuclear power plants, despite intense and increasing volcanic and seismic activity (the two being closely linked). ${ }^{31}$ And yet, as we have shown, the epidemiological, residential, and psychological effects of nuclear power cannot be managed, so one must question what drives the determination to persist on this path. It seems that the only remaining motivation is the ultimate power, the right of life or death over the 


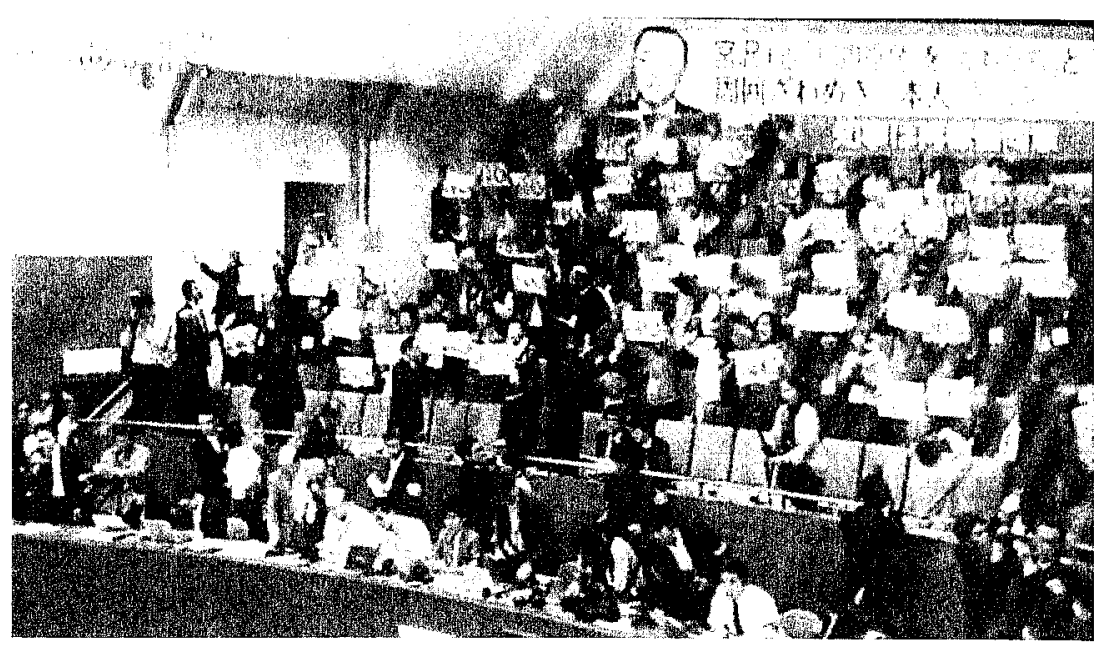

Fig. 6.4 Secne of the vote deciding to restart the Sendai (Ky'ūshu) nuclear power station: Minister of Track Y. Miyazawa, in reading out the decision, got the name of the plant wrong, thus betraying his disinterest and lack of involvement in local affairs, to then declare: "The committee is in unamimous agreement for restarting the power plant." This scene shows how, in democratic systems, the participation of the public is respected, indecd required, even if their opinions are not taken into consideration. One of the charactcristics of the nuclear state is that it stages such demonstrations of the democratic process. (NHK News, October 2014; Photo Cécile Asanuma-Brice)

whole of the earth's ecosystem. This quasi-divine right assumed by certain politicians is bolstered by an institutional system that contains enough safety valves to allow the strongest tensions to escape along the margins and ensure that the current system, democratic in name only, is self-sustaining.

The central role of deception in all of this initially revolted my naive self, but a reading of the works of philosophers of the $1970 \mathrm{~s}$ - which emerged out of two of the most terrible episodes of twentieth-century history, that is, World War II and the Vietnam War-taught me to temper my anger in order to transform it into more productive reflection. Hannah Arendt wrote on this subject:

Secrecy - what diplomatically is called 'discretion', ... - and deception, the deliberate falsehood and the outright lie used as legitimate means to achieve 
political ends, have been with us since the beginning of recorded history. "Truthfulness has never been counted among the political virtues, and lies have always been regarded as justifiable tools in political dealings. ${ }^{22}$

The process of lying goes hand in hand with the disconnection between knowledge and thought previously evoked, because it is necessary to extract our thinking from our environment so that it might imagine another, invented world (whether conceiving a better alternative or constructing a web of deceit). This removal of thought from the present reality is also, according to Arendt, what permits action. As action is the foundation of politics, so deception is inherent to political action. Nevertheless, that does not mean that one must accept the lies, cease denouncing them; on the contrary, it enjoins us to not be deceived by the elaborate political strategies of our different governments, nor to just passively await improvements in the situation that will never come.

\section{Notes}

1. "PM Abe Makes No Mention of 3 Non-Nuclear Principles in A-Bomb Anniversary Speech," Mainichi Sbimbun, August 6, 2015, http:// mainichi.jp/english/articles/20150806/p2a/00m/0na/021000c.

2. Here I take up a reflection developed in Jaime Semprun's fascinating work, La nucléarisation du monde (Paris: Gérard Lebovici, 1986).

3. Sezin Topçu, La France nucléaire: l'art de gouverner une technologie contestée (Paris: Éditions du Seuil, 2013).

4. Gabrielle Hecht, The Radiance of France: Nuclear Power and National Identity after World War II (Cambridge, MA: MIT Press, 2009).

5. "Japan Regains Nuclear Power Supply under Post-Fukushima Regime," Mainichi Shimbun, August 15, 2015, http://mainichi.jp/english/english/newsselect/news/20150814p2g00m0dm013000c.html.

6. "Kinkyūji no hibaku jōgen hikiagean matomaru wo shingi," (Settlement on rising the limit of radiation exposure in case of emergency) NHK News, July 15, 2015. http://www3.nhk.or.jp/news/genpatsu-fukushima/ $20150520 / 0520$ kinkyuuzi.html. "Genpatsusagyöin no hibakugendo age, kinkyūji 250 mirishiberutoni kiseian" (Proposal to raise the radiation limit of nuclear workers to 250 millisibel in case of emergency), Nikkei, August 15, 2015, http://www.nikkei.com/article/DGXLASDG08 HIQ_Y5A700CICR0000/.

7. Regarding this theme, see our article Cécile Asanuma-Brice, "Beyond Reality - or - An Illusory Ideal: Pro-Nuclear Japan's Management of Migratory Flows in a Nuclear Catastrophe," The Asia-Pacific Journal: 


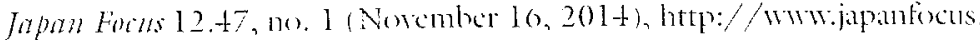

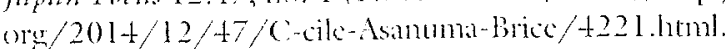

8. Klervi I exurand ot al., "Ionising Radiation and Risk of Death from I.cukaemia and I rmphoma in Radiation-Monitored Workers (INWORKS): An International Cohort Study," The Lanet Hotmatolomy 2, no. 7(2015): c276-81.

9. The INWORKS authors do not mention the databases collected and ana lized following the accident at Chemobyl.

10. The precautionary principle with regard to radioprotection when there is uncertainty as to the dose-effect connection.

11. As mar be seen in the documents of the Srmposium June 2-3,2015 at the Fukushima Medical Lniversity: workshop on questions of ethics in the area of radioprotection, organized by the Fukushima Medical University and the IC.RP.

12. Informal Comments, Second Asian Workshop on the Ethical Dimensions of the System of Radiological Protection, Fukushima Medical University, June 2015: http:/ www.icrp.org/docs/9/Second\%20Asian\%20 Workshop\%20l'rogramme.pdt.

13. Interview with a refugee nother, by Cécile Asanuma-Brice, May 18, 2015

14. "Jishu jinan jūtaku tcikvō, ninengoni shūryō he Fukushima-ken ga hōshin" (Fukushima prefecture plan to end housing for voluntary evacuees in two years), Asalji Sthimbun, May 17, 2015. http://wwwasahi.com/articles/ ASH5J5H83H5JUTILOOM.html

15. Results of a survey of the Fukushima Prefecture, January 30, 2015.

16. Cécile Asanuma-Brice, "À Fukushima, La Population Est Dans Une Situation Inextricable," CNRS Le Joumal, March 11, 2015, https:// lejournal.cnrs.fr/articles/a-fukushima-la-population-est-dansune-situation-inextricable

17. TADA Shinogi (2012), "Higashi nihon daishinsai niokeru ókynūjūka no kyokyüjitai to minashi kasetsu no kadai" (Questions regarding the provision of "emergency housing" and of "temporarily free housing" following the carthquake in eastern Japan) (Tokyo: Norin Chukin Research Institute, July 2012). https://www.nochuri.co.jp/periodical/soken/contents $/ 4381 . h \mathrm{hml}$

18. NHK realized a surver between November and December 2014 on 5000 inhabitants of the Fukushima prefecture. 1154 answered to three questions: Are you thinking of returning? $42.5 \%$ no. Have you staved in touch with your former friends/neighbors since the accident? At $46.4 \%$, these ties bave largely disappeared.) hetp://www3.nhk.or.jp/news/shinsai-movic/

19. "Genpatsu jiko kara yonenhanm hinanshijikaijo Fukushima Naruhachō" (41/2 Years after the Accident, the Evacuation Order Is Lifted for the Town of Naraha in Fukushima Prefecturc) Asahi Strimbatn, September 5, 2015, http://wwwasahi.com/articles/ASH945DW2H94UGTB00P.html. 
, 2014), http://www.japanfocus. c/ 422 l.html.

ation and Risk of Death from Monitored Workers (INWORKS): ncet Haimatology 2, no. 7 (2015):

1 the databases collected and anayl.

to radioprotection when there is son.

Symposium June 2-3,2015 at the don questions of ethics in the area kushima Medical University and Pis

Whop on the Ethical Dimensions Whushima Medical University, 6ocs $/ 9 /$ Second $\% 20$ Asian $\% 20$ 7.7.

Shuma-Brice, May 18, 2015 17 tukushima-ken ga hōshin" W Voluntary evacuees in two WWwasahi.com/articles/ 7x+y

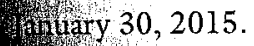

Hith Est Dans Une 17x11, 2015, https:// Wation-est-dansxy Karu okyūjūka no teing the provi17 sing" following 4. Wen Institute, 2/soken/con(1)

014 on 5000 Thee ques74 in touch X These ties Hovie/

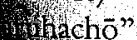
10wn 1015 .
20. Hannah Arendt, Corises of the Republic: Lying in Politics; Civil Disobedience; On Violine; Thonghts on Politics and Revolution (New York: Harcourt Brace Jovanovich, 1972).

21. Asanuma-Brice, "Beyond Reality."

22. Interview by Cécile Asanuma-Brice, villiage of Ōtama, May 21, 2015.

23. Ulrich Beck, Risk Society: Towards a New Modernity (London \& Newbury Park, CA: Sage Publications, 1992).

24. "Perte Astronomique de Près de 5 Milliards D'curos Pour Arevi En 2014," Capital, Fcbruary 23, 2013, http://www.capital.fi/bourse/actualites/perte-astronomique-de-pres-de-5-milliards-d-euros-pourareva-en-2014-1014891; Patrick Roger, "La facturc du nucléaire a flambé depuis 2010," Le Monde, May 27, 2014, sec. Économic, http://www. lemonde.fr/economie/article/2014/05/27/facture-du-nucleaire-1alerte-de-la-cour-des-comptes_4426678_3234.html; See also: Jusen Asuka (Tōhōku University), Seung-Joon Park (Kwansei Gakuin University), Mutsuyoshi Nishimura (Former Ambassador for the United Nations climate change negotiations), Tōru Morotomi (Kyōto University) (2014): "The figures for nuclear power generation costs did not include sufficient back-end costs of nuclear waste storage, decommissioning costs of failed reactors, and especially indemnification insurance. If these costs were included, the cost would no doubt exceed $100 \mathrm{yen} / \mathrm{kWh}$, as indicated in some studies (Mikami, 2013).... In other words, the cost of nuclear power generation seems to be lower than other energy sources simply because such cost does not include external costs, which are quite significant. In terms of not reflecting the true cost, operating a nuclear power plant is like driving a car without automobile liability insurance and its relatively high cost competitiveness is decreasing rapidly." In Nuclear Power is not the Answer to Climate Change Mitigation, January 2014, http://www.cneas. tohoku.ac.jp/labs/china/asuka/_src/2014/nuclear_power-climate_ change_enver2.pdf

25. For 2010 , of French public spending on energy R\&D, $42 \%$ was for nuclear (fusion and fission), $5 \%$ for hydrogen and fuel cells, and $12 \%$ for renewable energy: http://energie.eelv.fr/wp-content/blogs.dir/118/files/2012/09/ Financenemnt-RD.jpg

26. Utagawa Manabu, "Kokunai no onshitsukōka gasu haishutsu shōmetsu kanōsei shōene taisaku wo chūshin ni" (Regarding the possibility of canceling greenhouse effect gas emission for a policy of energy saving), Research Institute of Science for Safety and Sustainability, 2015: http://www. kikonet.org/wp/wp-content/uploads/2015/02/utagawa_ppt.pdf

27. Sonal Patel, "Turkey Prepares to Host First ATMEA 1 Nuclear Reactors," POWER Magazine, July 1, 2013, http://www.powermag.com/ turkey-prepares-to-host-first-atmea-1-nuclear-reactors $/$. 
28. "Vente Darions Rafale Au Qatar: Pourcuos Lenjeu de La Transaltion Depasse Largement Les Arions," Athmtion, May 1, 2015, hetp:/ ww

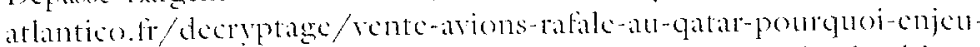
transaction-depalsse-laregenent-arions-jean-bernard-pinatet-roland-lombardi-2122827.html.

29. "I a Premiere Commission Adepte 28 Projets de Résolution, Dont 21 P'ar

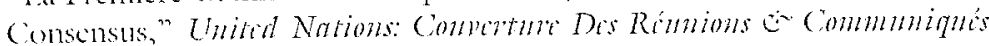
di Press, octoler 31, 2014, http://wrw.un.org/press/ti/201t/ agdsi3515.doc.htm. (in French)

30. Hans Jonas, Le Principe responsabilité: mat étbique pou la civilisation tothnolonique (Paris: Fiditions du Cerf, 1990).

31. The Japancse Meteorological Agency reported a rise in magma following the 2011 earthquake, which resulted in several volcanic cruptions, forcing cracuations of nearby residents. The main incidents were as follows: on September 27,2014, the cruption of Ontakesan (between Nagano and Shiga Prefectures) caused 63 deaths; on May 3, 2015, the eruption of a volcano at Hakonc (Kinagawa Prefecture); on May 29, 2015, the eruption of a volcano at Kuchinocrabujima (Kagoshima), located some $70 \mathrm{~km}$ from the Sendai nuclear power plant on Kyûshu, which has just been restarted; on June 16,2015, the eruption of a voleano at Asamayama (Nagano Prefecture.

32. Hannalh Arendt, "Lving in Politics: Reflections on the Pentagon Papers," in Crises of the Republic: Lying in Politics; Civil Disobediene; On Violence; Thonghts on Politics and Revolution (New York: Harcourt Brace Jovanovich, 1972), 4; originally appeared in The New Yow Rewion of Books 17 no. 8 (November 18, 1971): 30-39, avaliable online at http://www.nybooks. $\mathrm{com} /$ articles/archives/1971/nov/18/lying-in-politics-reflectionson-the-pentagon-pape/ 